\title{
Transitioning to Sponge Cities: Challenges and Opportunities to Address Urban Water Problems in China
}

\author{
Chris Zevenbergen ${ }^{1, *}$, Dafang Fu ${ }^{2,3}$ and Assela Pathirana ${ }^{1}$ \\ 1 Department of Water Science Engineering, IHE Delft Institute for Water Education, \\ 2611 AX Delft, The Netherlands; assela@pathirana.net \\ 2 School of Civil Engineering, Southeast University, Nanjing 210096, China; fdf@seu.edu.cn \\ 3 Southeast University-Monash University Joint Research Centre for Water Sensitive Cities, \\ Nanjing 210096, China \\ * Correspondence: c.zevenbergen@un-ihe.org; Tel.: +31-653-599-654
}

Received: 16 August 2018; Accepted: 6 September 2018; Published: 12 September 2018

\begin{abstract}
At present, the Sponge City Concept (SCC) is gaining ground, Sponge Cities technologies are becoming more and more accepted by Chinese city governments, and the first best practices are being shared. However, there are still many challenges ahead which hamper effective implementation and upscaling. This paper presents an overview of some opportunities and constraints for the take up of this approach and has drawn upon international experiences. In China at the national level, the State Council has set a progressive target for the SCC initiative to be achieved in 2030. This target seems to be ambitious as the time needed for integrative planning and design and implementation is much longer than traditional sectoral approaches often omitting to address social well-being, the (local) economy, and ecosystem health. This particularly holds true for the existing building stock. Transforming the existing building stock requires a long-term planning horizon, with urban restoration, regeneration, and modernization being key drivers for adapting the city to become a sponge city. A key challenge will be to align the sponge city initiative (SCI) projects with infrastructure and urban renovation portfolios. Moreover, substantial investment needs and a lack of reliable financing schemes and experience also provide a huge challenge for China. This calls for an integrative opportunistic strategy that creates enabling conditions for linking the SCI investment agenda with those from other sectors. These transformations cannot be made overnight: completing the transformation process will typically take a life time of one generation. The progress in sustainable urban water management is also impacted by innovations in technologies as well as in management strategies. These technological innovations create fertile ground for businesses to adapt state-of-the-art developments from around the world and contextualize them into fit-for-purpose products. China is well-placed to play a leading role in this process in the coming decade.
\end{abstract}

Keywords: sponge city; water sensitive city; urban water cycle; nature-based solutions; resilience; urban flooding; eco-restoration; stormwater management; low-impact development; sustainable drainage systems

\section{Introduction}

Cities around the world are facing a dire need to take action to manage water-related risks that are exacerbated by forces of change (e.g., climate, urban growth). At the same time, they encounter the challenge to become more sustainable and adaptive to cope with resource restrictions, environmental concerns, and the urgency and uncertainties posed by anticipated future change. Consequently, they have to capture the synergies between sustainability planning and urban water management 
and mainstream adaptation into all aspects of urban development, service provision, and emergency management [1-3]. Particularly in relation to extreme weather events, there is a call for adaptation of infrastructure and the spatial layout of built-up areas to reduce risk [4-6].

China is a country with severe water problems, both in terms of water scarcity and flooding and water quality. Due to the rapid progress of industrialization and urbanization as well as to increasing frequencies of extreme weather events, urban water problems have become very prominent in the socio-political discourse in the country during the last two decades [7]. The damages caused by floods are exponentially increasing. Amongst these problems, flooding ranks on the top of the most destructive natural hazards in China. These damages are concentrated in cities and are to a large extent a result of heavy summer rainfalls. Their frequencies and intensities have significantly increased in the past few decades [8].

As a response to those increasing flood impacts the Chinese Central Government called in 2013 for widespread uptake of the "Sponge City" approach across China and launched a program to provide financial support to foster implementation of this approach in a selection of pilot cities $[9,10]$. The Sponge City approach aims to enhance infiltration, evapotranspiration, and capturing and reuse of stormwater in the urban environment.

At present, the Sponge City approach is gaining ground, Sponge Cities technologies are becoming more and more accepted by city governments, and the first best practices are being shared. However, there are still many challenges ahead which hamper effective implementation of Sponge Cities technologies in the selected pilot cities and adoption of the approach as a steering concept in urban planning by the remaining 600 ( 1 million plus citizens) cities in China. In the coming decade, innovations in research, education, and technology are urgently required to design, engineer, and construct Sponge Cities across the whole of China [7].

An important requirement for implementing the Sponge City program is to learn from similar experiences from around the world. While the term "Sponge City" originates from China and aims to mimic natural hydrological and ecological processes, the last three decades have seen numerous developments in using nature-based solutions to address urban water problems particularly in the U.S., E.U., and Australia [11-14]. Practical experiences with concepts such as low-impact development, sustainable (urban) drainage systems, water sensitive cities, and green infrastructure, while not identical, are more and more generating useful lessons and inspiration for the design and implementation of the Sponge Cities approach and technologies [14,15].

The objective of this paper is to give a brief overview of the recent developments and challenges in the area of urban water management from a global perspective relevant for the Sponge City Program. The first section of this paper presents some key features of the Sponge City Program and the challenges it is currently facing, followed by the second section that provides recent international experiences in in this domain captured by the term Integrated Urban Water Management (IUWM). Finally, based on the previous sections, the last section will give an outlook on what the future holds for the Chinese context and beyond.

\section{Sponge Cities Challenges}

China has experienced unprecedented urban expansion and growth in wealth since the 1980s. The urban population has increased a 6-fold in number since 1980, which is about 750 million people. A similar relative increase in urban population in Europe took place over a time period of more than 120 years. At present, the urban population in China is more than $54 \%$ of the total population and the total urbanized area is about $44.5 \times 103 \mathrm{~km}^{2}$.

During this process of urbanization, the design, implementation, and maintenance of the underground infrastructure, such as the drainage system, of built-up areas could not keep pace with the aboveground urban development processes and were not part of an integrated planning strategy. The design of these urban drainage systems is often based on a single design storm and thereby does not consider a range of plausible ways in which flood risk may shift in the future due to, 
for instance, land-use change. For example, the capital city of China, Beijing, has witnessed more than a doubling of the total land coverage in the past 10 years and several devastating flood events in that same period. The affected city areas of Beijing have been constructed in the last two decades. Various studies have indicated that one of the major causes of Beijing's recent flood events is a lack of surplus capacity of the drainage system to cope with extreme weather events [16]. Addition, these studies revealed that these urban areas did not have sufficient retention capacity to allow for infiltration and retention of stormwater during heavy downpours. Another cause of increasing urban flooding in China is that many cities have not preserved their indigenous water infrastructure systems, such as city lakes and ponds, canals, and peri-urban wetlands. In most cases, urban expansion has resulted in a staggering loss of unpaved, green, or open areas and loss of water bodies in the peri-urban areas as well as within the old city centres. As the process of urbanization will continue to rise in China for the next two decades and probably beyond, it follows from the above that if no proper responses will be taken in the near future (to move cities away from the business as usual scenario), these cities are predisposed to experience more frequent flooding with increasing consequences.

Among the current 654 cities in China, 641 of them are exposed to frequent flooding [8]. In 2015, more than 150 cities were affected by serious flooding causing a total direct flood damage of about 160 billion RMB (or 22 billion Euro) [8]. Over the past 10 years, 2010 ranks number one in terms of the number of affected cities by flooding and the total direct flood damage. More than 250 cities were affected with a total direct damage of more than 350 billion RMB (or 46.9 billion Euro) in that year.

It should be noted here that information publicly available on the indirect damage of flooding occurring in Chinese cities is relatively scarce compared to those reported on the direct consequences of flood disasters to infrastructure and property (damage to buildings). One of the possible reasons for this is that the indirect consequences (for instance on urban transport, property value) are generally spread over a much wider area and therefore more difficult to assess than localized direct flood impacts. Hence, flooding may indirectly affect the services in cities. If disrupted or destroyed, these would have a serious impact on the well-being of citizens and the operation of an organization, sector, region, or government. Based on international experiences, indirect losses are generally larger than direct flood losses in the case of extreme flood events. By contrast, the direct losses of more frequent flooding seem to outweigh the indirect economic losses. Indirect economic losses, however, depend on contextual factors, such as flood exposure and sensitivity of critical infrastructure comprising, amongst other things, energy supply systems, transport services, water supply, and information and communication services.

\subsection{The Sponge City Concept (SCC)}

The term "sponge city", used in the context of urban water, did probably not originate from China. For example, Rooijen, et al. [17] used the term to describe the potential of stormwater runoff from the city of Hydrabad in India to offset the impact of water demand of the city on the surrounding agricultural water supply. Shannon [18] describes an urban design project for Vinh city, Vietnam proposed as a "City as Sponge", which embeds a system of alternating low-land and high-land strips that could allow for seasonal floods of the Lam River and Vinh River to penetrate the territory, yet not destroy urbanity. In the project, the existing waterways are developed to be a completely open and interconnected network in order to maintain their irrigation and drainage functions as well as to become a local transportation system [19].

The Sponge City (pilot) program was launched at the end of 2014 under the direct guidance and support of the Ministry of Housing and Rural-Urban Development (MOHURD), the Ministry of Finance, and the Ministry of Water Resources (MWR). The general objectives of the concept entail "restoring" the city's capacity to absorb, infiltrate, store, purify, drain, and manage rainwater and "regulating" the water cycle as much as possible to mimic the natural hydrological cycle. Hence, a "Sponge City" is a city that has the capacity to mainstream urban flood risk management into its urban planning policies and designs. It should have the appropriate planning and legal frameworks 
and tools in place to implement, maintain, and adapt the infrastructure systems to collect, store, and purify (excess) rainwater. In addition, a "sponge city" will not only be able to deal with "too much water", but also reuse rain water to help to mitigate the impacts of "droughts". The anticipated benefits of a Sponge City are: (i) a reduction of the economic losses (due to flooding), (ii) an enhancement of the livability of cities, and (iii) the establishment of an environment where investment opportunities in infrastructure upgrading and engineering products and new technologies are created and fostered. The State Council issued a guideline on 16 October 2015, referred to as the "Directive on promoting Sponge City Construction", which sets out the target that $20 \%$ of the urban areas of Chinese cities should absorb, retain, and reuse $70 \%$ of the rainwater by 2020 . By 2030, this percentage should increase up to $80 \%$.

To meet these targets, provincial governments in China at all institutional levels have to support the implementation of Sponge City Construction in new built-up areas of city districts, industrial parks, and development zones. In existing urban areas, retrofitting of neighborhoods, refurbishment of existing buildings and infrastructure, and other rebuilding activities of old city areas should comply with Sponge Cities Construction. These autonomous dynamics should be exploited to adapt cities to better manage the water cycle. Hence, these activities should be aligned with interventions required to transform these areas into areas that meet the targets of Sponge Cities.

The public sector (national and city governments) is coordinating and managing the implementation of Sponge Cities Construction. The private sector will have to play an important role in allocating additional resources. Various fund-raising methods, including public-private partnership and franchising, will be promoted and required to meet the targets of the guideline. The central government will support the implementation of Sponge Cities Construction with an allocated central budget, governments at provincial levels should increase investments, and governments at city levels should prioritize Sponge Cities projects in mid-term financial budgets and annual construction plans. Banks will also be given incentives to provide mid- and long-term loans.

The Ministry of Housing and Urban-Rural Development (MOHURD), which is responsible for the implementation of Sponge City Construction, has estimated that the required investments will be about 100 to 150 million RMB per $\mathrm{km}^{2}$ (or 13.4 to 21.1 million Euro per $\mathrm{km}^{2}$ ).

\subsection{Pilot Sponge Cities}

As of 2015, MOHURD has invested about 6.9 billion RMB (or 0.5 billion Euro) per year in the first batch of 16 pilot projects. This subsidy varies between 600 and 400 million RMB (or 54 million Euro) per city. The total investment required to implement the Sponge City approach in these 16 pilot cities is estimated at 86.5 billion RMB (or 11 billion Euro). With a total surface area of $450 \mathrm{~km}^{2}$, the average investment will be around 190 million $\mathrm{RMB} / \mathrm{km}^{2}$ (or 23 million Euro $/ \mathrm{km}^{2}$ ).

It follows from the above that the subsidy from the central government is far from enough to finance the implementation of the projects. The majority of the financial resources need to come from the cities themselves and the private sector. Local governments are generally very keen to become a national pilot of the Sponge City Program as in times of economic slowdown they expect that the pilot status will bring in capital to the city, attract private investments, and enhance the investment climate. However, the private sector is still reluctant to engage as the business opportunities are not self-evident. It is assumed that the implementation of Sponge City Construction should be a public responsibility and not a private matter.

In 2016, a second batch of 14 pilot cities was selected by MOHURD. These cities include, amongst others, Beijing, Tianjin, Shanghai, and Shenzhen. The selection of these cities has been made on the basis of an application document pertaining to the commitment of the cities to invest in the implementation of Sponge City Construction.

Based on the information publicly available, it can be discerned that in 2016 about 20 cities have invested 267 billion RMB (about 36 billion Euro), which on average is about 13.4 billion RMB (or 1.8 billion Euro per city). 
There is limited insight into the costs of available Sponge City technologies both in terms of direct costs and maintenance costs. They are dependent on the local context, which may vary considerably. A fair cost comparison should also consider the additional benefits of a sponge city for its residents, such as recreational areas, a healthier environment, increased biodiversity, and cooler temperatures. It is likely that the economic case for such solutions will become clearer as China is moving ahead with the implementation of the Sponge City pilot projects.

\section{IUWM: International Experiences}

It is increasingly recognized that floods, droughts, and all sorts of uses of water have to be managed in an integrative way requiring an approach that acknowledges the importance of the water cycle as a coherent and many-faceted system [1,20-23]. Integrated approaches to urban water management have been around for decades. Their popularity has grown rapidly since the early 1990s. Probably the best example of such an integrative approach is the concept of integrated urban water management (IUWM) [20]. This concept has multiple definitions and interpretations, but what they share is that they aim to integrate the management of different sub-systems of the urban water cycle, namely, water supply, groundwater, wastewater, and stormwater [24]. The SWITCH project was one of the first research projects which has developed, applied, and demonstrated IUWM concepts and approaches in 12 cities across the world [25].

Looking at the way different cities and regions historically approached IUWM shows the pattern that, depending on the acute problem they faced, they had chosen the "point-of-departure" for IUWM. For example, in Japan the ideas of IUWM originated from addressing the peak runoffs by infiltration technologies [26]. In the United States, it was largely the need for stormwater quality management, and in the Netherlands (and arguably in Western Europe) the point-of-departure was the intention of limiting the stormwater peaks entering the combined sewer systems (disconnection). The primary driving forces behind SCC in China are the rising flood damages caused by rainstorms as described above. However, it should be noted that Chinese cities vary in terms of hydrological, socio-economic, and historical conditions and thus may have very different acute water issues ranging from urban/river flooding to a lack of water resources to water quality issues. Some "non-water" issues, such as urban air quality, are also contributing drivers in many cases.

Nowadays, IUWM is sometimes seen as a strategy for achieving the goals of Water-Sensitive Urban Design (WSUD) [24]. Along similar lines as the Sponge Cities Concept (SCC), WSUD seeks to change the impact of urban development on the natural water cycle based on the premise that, by managing the urban water cycle as a whole, "a more efficient use of resources can be achieved providing not only economic benefits, but also improved social and environmental outcomes" [12,27]. WSUD brings together "water-sensitive" and "urban design". The term Water-Sensitive refers to a state in which "residents, community organisations, businesses and land developers, and governmental organisations value water as a finite and vulnerable resource that is critical to the liveability of livelihoods, and that this is reflected in their behaviours related to dealing with water resources" [28]. Urban Design refers to the process of shaping neighbourhoods, districts, and entire cities with the aim of creating functional, attractive, and sustainable urban areas. Hence, it is connected to planning and architectural design. Ideally, WSUD is the process that brings about Water-Sensitive Cities (WSC) as the outcome [11,29]. The Australian National Water Initiative defines WSUD as "the integration of urban planning with the management, protection, and conservation of the urban water cycle that ensures that urban water management is sensitive to natural hydrological and ecological processes" [29]. It follows from the above that WSUD and SCC are concepts that embrace water sustainability and environmental protection, which are closely linked with urban design and explicitly aim to harness all of the opportunities in the water cycle. Sustainable urban drainage systems (SUDS) are technologies which aim to offset the excess runoff created as a result of urbanization by promoting infiltration, detention, retention, and treatment as close as possible to the generating source. SUDS (Sustainable Drainage Systems, U.K.) and its equivalent BMPs (Best Management Practices, U.S.), in contrast to WSUD, typically take 
one component of the urban water cycle, stormwater, as the point of departure, albeit ideally in a multifunctional manner [30]. SUDS rely on natural processes, such as evapotranspiration, infiltration, and natural treatment, and often complement traditional "grey" infrastructure. Green infrastructure (GI) is often defined as a planned approach to the delivery of nature in the city in order to provide benefits to residents [31,32]. GI uses natural or semi-natural systems, such as Nature-Based Solutions (NBS), to provide water resources management options with benefits to providing important regulatory services, such as pollution filtration, water treatment, flood risk reduction, and modulation of high urban temperatures. The challenge of maximising benefits and value from GI investment is receiving much attention by both the scientific community and the finance sector as the awareness is growing that the broader value of GI needs to be considered when dealing with any aspect of water systems [32-34].

In 2016, the International Water Association launched the Principles for Water Wise Cities [34]. The IWA has developed the Principles for Water Wise Cities to catalyze a shift in the current water management paradigm towards a more sustainable state in order to make cities more resilient and livable. The Principles for Water Wise Cities outline a framework to assist urban leaders and professionals to develop and implement their vision for sustainable urban water and resilient planning and design in their cities. Through the Principles, urban leaders, water managers, citizens, and other stakeholders are inspired to collaboratively find solutions on urban water management challenges and implement water wise management strategies through a shared vision that will enable the development of flexible and adaptable cities.

In summary, IUWM, SCC, WSUD, SUDs, and GI are terms that, while each being unique, have considerable overlap as illustrated in Figure 1.

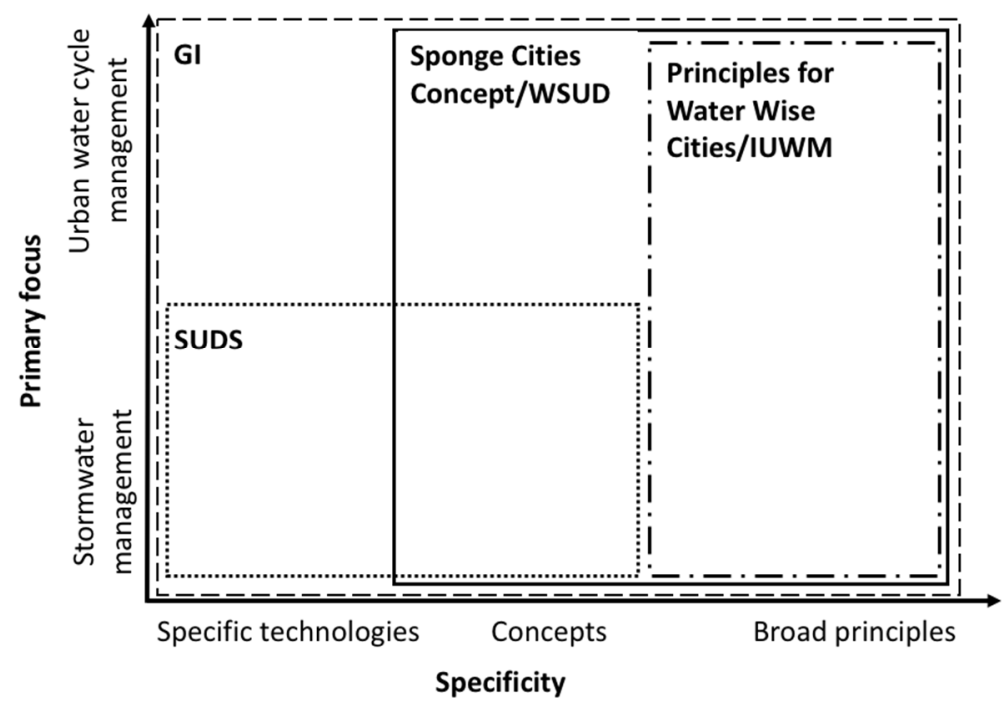

Figure 1. A classification of terminology related to the domain of integrated urban water management (IUWM) according to the terms' specificity and their primary focus (modified from [24]). GI, green infrastructure; SUDS, sustainable urban drainage systems; WSUD, water-sensitive urban design.

\section{SPC China's Experience}

Since the launching of the SPC programme in 2014, China has started a number of specific SPC projects in different parts of the country. In April 2015, the first 16 pilot cities were selected and this was expanded with another 14 new cities in 2016. The pilot sites cover a range of different climatic regions, though almost no cities are included from the western part of the country. Ding, et al. [35] observe that the range of SPC technologies considered in the SPC programme is limited. This is likely due to the fact that most pilot cities are located in the central and southeastern regions, where annual precipitation ranges from 410 to $1830 \mathrm{~mm}$. 
In each of these pilot cities, an area greater than $15 \mathrm{~km}^{2}$ was designated as pilot. Most of these pilot areas are green-field developments [35]. Urban retrofitting opportunities are largely unidentified in the programme. Li et al. [10] describes case studies in several pilot cities. Jinan city in Shandong Province has cultural heritage value due to its famous natural springs. The problems that are addressed by SPC here include spring protection, flooding, water shortage, and water pollution and the technologies used consist mainly of stormwater detention, storage, and infiltration with possible reuse. Baicheng city in Jilin Province on the other hand has harsh winter conditions. The main issues faced by Baicheng during the Low Impact Development (LID) system construction process are the soil freeze-thaw process, environmental pollution of deicing salts, and restoring alkaline lands.

During the period of the launch of SPC in 2014 up to the present time, China has implemented a number of SCP projects and some comparative and analytical studies were done by researchers on the overall experience. Dai, et al. [36], using Wuhan City as a case study, observed that the government in China plays a significant role and that civil society is merely the recipient. They recommend that the government should slow down the implementation of this ambitious programme and help society and the private sector to catch up and effectively participate. Ma, et al. [37] agree, stating that inadequate supervision and extensive construction are the critical reasons that hinder a sponge city from developing healthily and sustainably. Researchers observe that there are considerable knowledge gaps in the areas of finance and cost of sustaining a sponge city program in larger areas in cities, the co-ordination across bureaus, the public perception and support, the monitoring and evaluation of the effectiveness of the sponge city technologies and program, etc., which remain a challenge [38]. They recommend that China should strengthen their international cooperation and collaboration so that they are able to gain from the experience of institutions around the world.

\section{How to Get There?}

Cities are adaptive, dynamic systems. They face changing environments and adapt to these changes [39]. Over a longer historical period, cities have always successfully adapted to changing environmental conditions. However, what is being observed today is that rapid urbanization, although leading to an increase of economic and social wealth, has also increased the number of people and assets exposed to water-related disasters. Water-related disasters, such as floods, have become more devastating than in the past due to an excessive concentration of population and wealth [40]. The "temporized" developments of cities in the past allowed them to learn and adapt to changing environmental conditions and increasing risks. However, today, due to the unprecedented rate of urbanization, cities do not have sufficient time to learn from mistakes to build adaptive capacity. This lack of adaptive capacity is exacerbating the trend of increasing water-related risks of cities due to a combination of the following "imperfections", which have been nested in current urban development processes [41]:

(i) Encroachment and expansion of urban developments onto flood plains and lowlands resulting in a loss of the natural water retention capacity of peri-urban areas;

(ii) Redevelopment and densification of built-up areas through "infill" of remaining open (green/blue) spaces, leading to an overall density increase and subsequent increase of surface sealing and disruption of the natural drainage channels; and

(iii) Increasing interdependency on more diversified infrastructure and a reduction in safety margins due to ageing and deferred maintenance.

It becomes increasingly important that cities have to build capacity to adapt proactively to the rapid changes they are currently facing and to anticipate and deal with disturbances and shocks, such as extreme weather events. They have to adopt flexible, adaptable, and distributed solutions for urban water management, which are embedded in a long-term integrative and adaptive strategy [2,42]. Monitoring and evaluation will be required to assess the effectiveness of interventions and to allow for timely adjustment of the strategy. 
In China at the national level, the State Council has set a progressive target: the SCC initiative is to be achieved in 2030 (see previous section). This target seems to be ambitious as the time needed for integrative planning and design and implementation, given the technical, governance, and financial challenges to adopt a broad view on how to manage the present and future water-related risks, is much longer than traditional sectoral approaches often omitting to address social well-being, the (local) economy, and ecosystem health. For the existing urban fabric, the management debt from the past in achieving the standards and goals of flood protection and drainage system upgrading across cities needs to be resolved first [43]. Transforming the existing building stock requires a long-term, adaptive, and opportunistic strategy, with urban restoration, regeneration, and modernization being key drivers for adapting the city while offering opportunities to align the sponge-city initiative (SCI) projects with infrastructure and urban renovation portfolios $[2,44,45]$. The substantial investment needs and a lack of reliable financing schemes and experience also provide huge opportunities for China as they call for a strategy that creates enabling conditions for linking the SCI investment agenda with those from other sectors. These transformations cannot be made overnight: completing the transformation process will typically take a life time of one generation.

From the viewpoint of urban development, typically three distinct zones can be discerned (see Figure 2). The first is the historical city center (zone 1), which has the oldest building stock and sometimes monuments or buildings of historical value. Surrounding this historical center is an established urban zone (zone 2), which is rapidly undergoing densification. In the periphery (zone 3 ), there is an ever-expanding urban fringe that consists mainly of newly built areas. Each of these zones require a distinctly different strategy under SCC. In the historical centre (zone 1), the preferred strategy, referred to as "accept and accommodate", is to prevent floodwater coming from the surrounding areas to enter this zone during periods of heavy rainfall. The historical buildings will be protected against floodwater and floodwater and excessive rainwater in exceptional circumstances will be allowed to enter into or around the sites in a controlled and predetermined manner. In zone 2, the strategy is to "adapt and retrofit" the existing urban fabric and aligns with autonomous urban regeneration processes to restore the health of waterways, mitigate flood risk, and to create public spaces that harvest, clean, and recycle water. This transformation process is slow and will likely take a few decades to reach full transformation. Finally, in zone 3, the strategy aims to create "water-sensitive developments" from scratch (tabula rasa) and newly developed buildings and public spaces will fully comply with the SCC standards (such as to allow for green roofs, underground storage in the floodplain, and ground measures, such as swales and rain gardens in the floodplain, where rainwater is collected within a communal harvesting system).

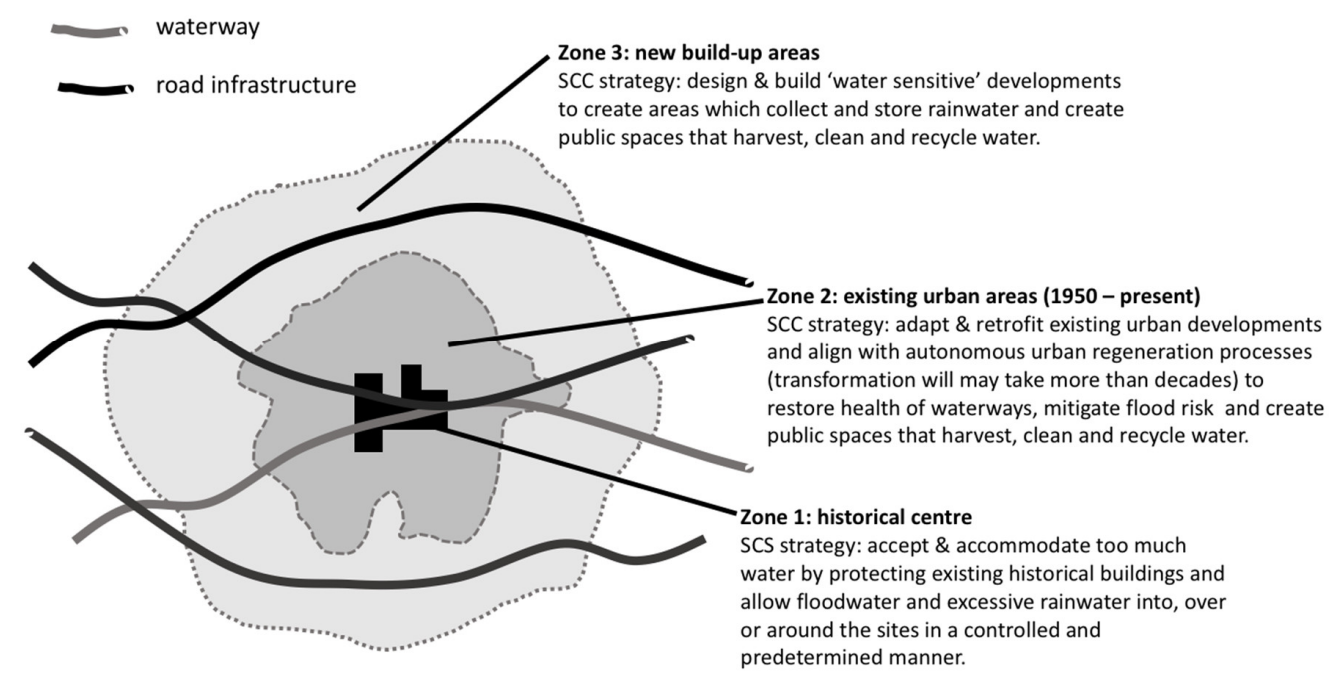

Figure 2. Schematic presentation of a typical layout of a typical Chinese city and associated strategies related to the different zones. SCC, Sponge City Construction. 
It is difficult to assume that Chinese cities have the capability to leapfrog directly into a sustainable future while avoiding the negative consequences associated with the "traditional" transition pathway to a water-sensitive city and thus circumvent the evolutionary step of managing the water cycle in a segmented manner. This will require customized strategies as depicted above placing water more centrally within the urban (re)development process and taking into account the opportunities and constraints imposed by the local context utilizing synergies with the management of other urban systems and services. The SCC sets out targets for the take up of such an approach, but the translation of this approach into feasible and practical customized strategies is still a challenge. The concept of "leapfrogging" has drawn the attention of both developing and developed countries as well as international organizations to create a strategy that responds to the water challenges that cities are facing [46]. The literature on leapfrogging concepts in sustainability transitions is scarce $[47,48]$ and very few studies in this field related to the Chinese context have been conducted. Among them, the most relevant are low carbon energy technology and new energy and wastewater treatment technologies $[49,50]$. These experiences reveal that technological innovations are necessary to leapfrogging; however, that itself is not sufficient. Leapfrogging entails not only technological innovation but innovations in governance that support the development of customized strategies capturing a portfolio of local management policies and measures to be implemented at various spatial scales ranging from the very local scale to the scale of an entire city and even beyond. This will challenge existing organizational structures, governance mechanisms, beliefs, and traditions [30]. Hence, leapfrogging towards SCC includes the adoption of new governance approaches to support SCC transformation [51]. The pilot cities now emerging are generating practical experiences and tailoring existing concepts to a local context and some of them are experimenting with innovative technologies. It goes without saying that the capability of a city to leapfrog towards SCC also depends on the extent to which these experiences and outcomes are being effectively shared between the pilot cities as well as among other Chinese cities. This requires a well-designed city-to-city peer learning process that supports learning from experiments and full-scale projects between pilot cities and beyond $[24,52,53]$ That is why the capacity to learn and to engage in city-to-city networks of Chinese cities will play an imminent role in the process of leapfrogging and upscaling.

\section{Outlook}

China has the potential to play a leading role internationally in sustainable urban water management in the coming decade. There are several reasons that support this assertion. One is that existing urban environmental problems in China (such as water, but there are many others, such as air quality) are so pressing that they provide immediate-term incentives to invest resources to manage these problems. The Sponge Cities (pilot) program is a good example of such an immediate-term incentive. Another is that China has the ambition to play a leading role in science and technology globally. Therefore, it has dramatically increased its budget for innovation and strengthened its engagement in international research, such as in the Chinese European Water partnership (CEWP). It is to be expected that in the near future a combination of home-grown innovations, joint ventures with foreign companies, and modifications to existing technology will change significantly the way in which the water challenges of Chinese cities will be managed.

One type of innovation which is currently pushing developments in this area is the wide-spread use of crowdsourced data (CSD) in the context of participatory monitoring [54]. Early warning, real-time control systems and smart-phone-based sensors now emerging will disclose distributed monitoring capabilities at a fraction of the cost and effort compared to that of traditional monitoring systems [55-59]. These capabilities in conjunction with innovations in data management and participation related to the internet (such as device-generated content (the Internet of Things, IOT)), are providing unique opportunities to connect a large number of information generation endpoints (be it devices or humans) to the process of gathering relevant information. Particularly in the water management domain, these developments, increasingly referred to as "Web 3.0" [60,61] 
will likely change the way our water systems will be managed in the near future. For example, they will allow us to have a much more detailed, accurate, and (due to its decentralized nature) fault-tolerant flood forecasting/warning system in place, which builds upon multidirectional risk communication and massively distributed sources of information. It will also increase our capability to assess the performance (and quality) of urban infrastructure systems, such as urban drainage systems, road infrastructure, and pumps through real-time field monitoring using IOT devices. However, successfully applying crowdsourced data to environmental monitoring and forecasting (e.g., flood forecasting) comes with its own challenges [62]. For example, traditionally collected data (e.g., flow gauge measurements) and CSD (flood levels reported by citizens using their smartphones) have very different error characteristics. They cannot be used in conjunction without applying novel data-assimilation techniques. Here, urban water managers can learn from other fields; for example, atmospheric science [63].

Such innovations will not only create opportunities for cities in developed countries, such as China, to leapfrog into a more resilient and sustainable state, but also for cities in rapidly growing developing countries, particularly those with poorly developed water management systems. These innovations create fertile ground for businesses to adapt state-of-the-art developments from around the world and contextualize them into fit-for-purpose products. China is well-placed to play a leading role in this process.

Author Contributions: Conceptualization, C.Z., D.F. and A.P. Resources, C.Z., D.F. and A.P., Writing-Original Draft Preparation, C.Z., D.F. and A.P.; Writing-Review \& Editing, C.Z., D.F. and A.P.

Funding: This research received no external funding.

Conflicts of Interest: The authors declare no conflict of interest.

\section{References}

1. Harremoes, P. Integrated urban drainage, status and perspectives. Water Sci. Technol. 2002, 45, 1-10. [CrossRef] [PubMed]

2. Gersonius, B.; Nasruddin, F.; Ashley, R.; Jeuken, A.; Pathirana, A.; Zevenbergen, C. Developing the evidence base for mainstreaming adaptation of stormwater systems to climate change. Water Res. 2012, 46, 6824-6835. [CrossRef] [PubMed]

3. Kirshen, P.; Caputo, L.; Vogel, R.; Mathisen, P.; Rosner, A.; Renaud, T. Adapting Urban Infrastructure to Climate Change: A Drainage Case Study. J. Water Res. Plan. Manag. 2015, 141, 04014064. [CrossRef]

4. Dickson, E.; Baker, J.; Hoornweg, D. Urban Risk Assessments: Understanding Disaster and Climate Risk in Cities; World Bank Publications: Washington, DC, USA, 2012.

5. CIRIA. C635 Designing for Exceedance in Urban Drainage—Good Practice; CIRIA: London, UK, 2014.

6. Georgiadis, T.; Iglesias, A.; Iglesias, P. City Resilience to Climate Change. In Rooftop Urban Agriculture; Springer: Cham, Switzerland, 2017; pp. 253-262.

7. Jiang, Y.; Zevenbergen, C.; Fu, D. Understanding the challenges for the governance of China's "sponge cities" initiative to sustainably manage urban stormwater and flooding. Nat. Hazards 2017, 89, 521-529. [CrossRef]

8. Xiaotao, C. Flooding in China. Presented at the River Flows, St. Louis, MO, USA, 12-15 July 2016.

9. Jia, H.; Yu, S.L.; Qin, H. Low impact development and Sponge City construction for urban stormwater management. Front. Environ. Sci. Eng. 2017, 11, 20. [CrossRef]

10. Li, X.; Li, J.; Fang, X.; Gong, Y.; Wang, W. Case Studies of the Sponge City Program in China. In Proceedings of the World Environmental and Water Resources Congress 2016, West Palm Beach, FL, USA, 22-26 May 2016; pp. 295-308.

11. Wong, T. Water Sensitive Urban Design-The Journey Thus Far. Aust. J. Water Resour. 2006, 10, $213-222$. [CrossRef]

12. Brown, R.; Keath, N.; Wong, T. Transitioning to Water Sensitive Cities: Historical, Current and Future Transition States. In Proceedings of the 11th International Conference on Urban Drainage, Edinburgh, UK, 31 August-5 September 2008; pp. 1-10. 
13. Zhou, Q.; Panduro, T.; Thorsen, B.; Arnbjerg-Nielsen, K. Adaption to Extreme Rainfall with Open Urban Drainage System: An Integrated Hydrological Cost-Benefit Analysis. Environ. Manag. 2013, 51, 586-601. [CrossRef] [PubMed]

14. Butler, D.; Ward, S.; Sweetapple, C.; Astaraie-Imani, M.; Diao, K.; Farmani, R.; Fu, G. Reliable, resilient and sustainable water management: The Safe \& SuRe approach. Glob. Chall. 2017, 1, 63-77.

15. Arnbjerg-Nielsen, K. Past, present, and future design of urban drainage systems with focus on Danish experiences. Water Sci. Technol. 2011, 63, 527-535. [CrossRef] [PubMed]

16. Duan, W.; He, B.; Nover, D.; Fan, J.; Yang, G.; Chen, W.; Liu, C. Floods and associated spciioeconomic damages in China over the last century. Nat. Hazards 2016, 82, 401-413. [CrossRef]

17. Rooijen, D.; van Turral, H.; Wade Biggs, T. Sponge city: Water balance of mega-city water use and wastewater use in Hyderabad, India. Irrig. Drain. 2005, 54, S81-S91. [CrossRef]

18. Shannon, K. Water urbanism: Hydrological infrastructure as an urban frame in Vietnam. In Water and Urban Development Paradigms; CRC Press: Boca Raton, FL, USA, 2008; pp. 73-84.

19. Nguyen, P. Deltaic Urbanism for Living with Flooding in Southern Vietnam. Ph.D. Thesis, Queensland University of Technology, Brisbane, Australia, 2015.

20. Mitchell, V. Applying Integrated Urban Water Management Concepts: A Review of Australian Experience. Environ. Manag. 2006, 37, 589-605. [CrossRef] [PubMed]

21. Mostert, E. Integrated Water Resources Management in The Netherlands: How Concepts Function. J. Cont. Water Res. Educ. 2006, 135, 19-27. [CrossRef]

22. Santos, D.; van der Steen, P. Understanding the IUWM Principles: An Activity Based on Role Play Approach (for Facilitator and Specialists); UNESCO-IHE: Delft, The Netherlands, 2011; 66p.

23. Burn, S.; Maheephla, A.S.; Sharma, A. Utilising integrated urban water management to assess the viability of decentralised water solutions. Water Sci. Technol. 2012, 66, 113-121. [CrossRef] [PubMed]

24. Fletcher, T.; Shuster, W.; Hunt, W.; Ashley, R.; Butler, D.; Arthur, S.; Trowsdale, S.; Barraud, S.; Semadeni-Davies, A.; Bertrand-Krajewski, J.; et al. SUDS, LID, BMPs, WSUD and more-The evolution and application of terminology surrounding urban drainage. Urban Water J. 2014, 12, 525-542. [CrossRef]

25. SWITCH. SWITCH Approach to Strategic Planning for Integrated Urban Water Management (IUWM). 2010, p. 39. Available online: http://www.switchtraining.eu/fileadmin/template/projects/switch_training/db/ event_upload_folder/103/SWITCHtrategyplanningapproach28october.pdf (accessed on 10 July 2018).

26. Fujita, S. Measures to promote stormwater infiltration. Water Sci. Technol. 1997, 1997 36, 289-293. [CrossRef]

27. Salinas Rodriguez, C.; Ashley, R.; Gersonius, B.; Rijke, J.; Pathirana, A.; Zevenbergen, C. Incorporation and application of resilience in the context of water-sensitive urban design: Linking European and Australian perspectives. Wiley Interdiscip. Rev. Water 2014, 1, 173-186. [CrossRef]

28. Hoyer, J.; Dickhaut, W.; Kronawitter, L.; Weber, B. Water Sensitive Urban Design: Principles and Inspiration for Sustainable Stormwater Management in the City of the Future, 1st ed.; JOVIS Verlag: Hamburg, Germany, 2011; p. 118. ISBN 9783868591064.

29. Brown, R.; Rogers, B.; Werbeloff, L. Moving toward Water Sensitive Cities a Guidance Manual for Strategists and Policy Makers; Cooperative Research Centre for Water Sensitive Cities: Clayton, Australia, 2016; ISBN 9781921912351.

30. CIRIA. The SUDS Manual; CIRIA: London, UK, 2007; p. 606. ISBN 9780860176978.

31. Benedict, M.; McMahon, E. Green Infrastructure: Smart Conservation for the 21st Century; Sprawl Watch Clearinghouse: Washington, DC, USA, 2002; p. 36.

32. Foster, J.; Lowe, A.; Winkelman, S. The Value of Green Infrastructure for Urban; Center for Clean Air Policy: Washington, DC, USA, 2011.

33. Wise, S.; Braden, J.; Ghalayini, D.; Grant, J.; Kloss, C.; Macmullan, E.; Morse, S.; Montalto, F.; Nees, D.; Nowak, D.; et al. Integrating Valuation Methods to Recognize Green Infrastructure's Multiple Benefits. Low Impact Dev. 2010, 2010, 1123-1143. Available online: https://ascelibrary.org/doi/abs/10.1061/ 41099(367)98 (accessed on 21 July2018).

34. International Water Association (IWA). Principles for Water Wise Cities. For Urban Stakeholders to Develop a Shared Vision and Act towards Sustainable Urban Water in Resilient and Liveable Cities IWA Report; The International Water Association: London, UK, 2016; Available online: http:/ /www.iwa-network. org/wp-content/uploads/2016/08/IWA_Principles_Water_Wise_Cities.pdf (accessed on 21 July 2018). 
35. Ding, L.Q.; Ren, M.L.; Li, C.Z.; Wang, H. Sponge City construction in China: A survey of the challenges and opportunities. Water 2017, 9, 594.

36. Dai, L.; van Rijswick, H.F.; Driessen, P.P.; Keessen, A.M. Governance of the Sponge City Programme in China with Wuhan as a case study. Int. J. Water Resour. Dev. 2018, 34, 578-596. [CrossRef]

37. Ma, T.; Wang, Z.; Ding, J. Governing the Moral Hazard in China's Sponge City Projects: A Managerial Analysis of the Construction in the Non-Public Land. Sustainability 2018, 10, 3018. [CrossRef]

38. Chan, F.K.; Griffiths, J.A.; Higgitt, D.; Xu, S.; Zhu, F.; Tang, Y.T.; Xu, Y.; Thorne, C.R. "Sponge City" in China-A breakthrough of planning and flood risk management in the urban context. Land Use Policy 2018, 76, 772-778. [CrossRef]

39. Bai, X.; Surveyer, A.; Elmqvist, T.; Gatzweiler, F.W.; Güneralp, B.; Parnell, S.; Prieur-Richard, A.H.; Shrivastava, P.; Siri, J.G.; Stafford-Smith, M.; et al. Defining and advancing a systems approach for sustainable cities. Curr. Opin. Environ. Sustain. 2016, 23, 69-78. [CrossRef]

40. Estrada, F.; Botzen, W.J.W.; Tol, R.S.J. A global economic assessment of city policies to reduce climate change impacts. Nat. Clim. Chang. 2017, 7, 403-406. [CrossRef]

41. Zevenbergen, C.; Cashman, A.; Evelpidou, N.; Pasche, E.; Garvin, S.; Ashley, R. Urban Flood Management; CRC Press: Boca Raton, FL, USA, 2010; p. 340. ISBN 139780415559447.

42. Klijn, F.; Kreibich, H.; De Moel, H.; Penning-Rowsell, E. Adaptive flood risk management planning based on a comprehensive flood risk conceptualisation. Mitig. Adapt. Strateg. Glob. Chang. 2015, 20, 845-864. [CrossRef] [PubMed]

43. Liu, H.; Jia, Y.; Niu, C. "Sponge City" concept helps to solve China's urban water problems. Environ. Erath Sci. 2017, 76, 473. [CrossRef]

44. Veerbeek, W.; Ashley, R.; Zevenbergen, C.; Rijke, J.S.; Gersonius, B. Building adaptive capacity for flood proofing in urban areas through synergistic interventions. In Proceedings of the ICSU 2010 First International Conference on Sustainable Urbanization, Hong Kong Polytechnic University, Faculty of Construction and Land Use, Hong Kong, China, 15-17 December 2010.

45. Zevenbergen, C.; van Herk, S.; Rijke, J. Future-Proofing Flood Risk Management: Setting the Stage for an Integrative, Adaptive, and Synergistic Approach, Public Works Management E Policy; SAGE Publications: Los Angeles, CA, USA, 2017; Volume 22, pp. 49-54.

46. Clemens, M.; Rijke, J.; Pathirana, A.; Evers, J.; Quan, N. Social learning for adaptation to climate change in developing countries: Insights from Vietnam. J. Water Clim. Chang. 2016, 7, 365-378. [CrossRef]

47. Perkins, R. Environmental leapfrogging in developing countries: A critical assessment and reconstruction. Nat. Resour. Forum 2003, 27, 177-188. [CrossRef]

48. Goldenberg, J.; Oreg, S. Laggards in disguise: Resistance to adopt and the leapfrogging effect. Technol. Forecast. Soc. Chang. 2007, 74, 1272-1281. [CrossRef]

49. Sauter, R.; Watson, J. Technology Leapfrogging: A Review of the Evidence A Report for DFID; Sussex Energy Group SPRU (Science and Technology Policy Research), University of Sussex: Brighton, UK, 2008; p. 32.

50. Binz, C.; Truffer, B.; Li, L.; Shi, Y.; Lu, Y. Conceptualizing leapfrogging with spatially coupled innovation systems: The case of onsite wastewater treatment in China. Technol. Forecast. Soc. Chang. 2012, 79, 155-171. [CrossRef]

51. Rijke, J.; Farrelly, M.; Brown, R.; Zevenbergen, C. Configuring transformative governance to enhance resilient urban water systems. Environ. Sci. Policy 2013, 25, 62-72. [CrossRef]

52. Seymoar, N.-K.; Mullard, Z.; Winstanley, M. City-to-City Learning; Sustainable Cities: Vancouver, BC, Canada, 2009; Available online: http:/ / sustainablecities.net/city-to-city-learning/ (accessed on 20 January 2015).

53. Lundby, L.; Sjöberg, H. An Evaluation of City-to-City Learning in the Campaign Making Cities Resilient-Matching Criteria and Implementation; Report: 5420; Lund University: Lund, Sweden, 2013; ISSN: 1402-3504; ISRN: LUTVDG/TVBB-5420-SE.

54. Turreira-García, N.; Lund, J.; Domínguez, P.; Carrillo-Anglés, E.; Brummer, M.; Duenn, P.; Reyes-García, V. What's in a name? Unpacking "participatory" environmental monitoring. Ecol. Soc. 2018, 23, 24. [CrossRef]

55. Fienen, M.; Lowry, C. Social. Water-A crowdsourcing tool for environmental data acquisition. Comput. Geosci. 2012, 49, 164-169. [CrossRef]

56. Overeem, A.; Robinson, J.; Leijnse, H.; Steeneveld, G.P.; Horn, B.; Uijlenhoet, R. Crowdsourcing urban air temperatures from smartphone battery temperatures. Geophys. Res. Lett. 2013, 40, 4081-4085. [CrossRef] 
57. Certoma, C.; Corsini, F.; Rizzi, F. Crowdsourcing urban sustainability. Data, people and technologies in participatory governance. Futures 2015, 74, 93-106. [CrossRef]

58. Eggimann, S.; Mutzner, L.; Wani, O.; Schneider, M.; Spuhler, D.; Moy de Vitry, M.; Beutler, P.; Maurer, M. The potential of knowing more: A review of data-driven urban water management. Environ. Sci. Technol. 2017, 51, 2538-2553. [CrossRef] [PubMed]

59. Wang, R.; Mao, H.; Wang, Y.; Rae, C.; Shaw, W. Hyper-resolution monitoring of urban flooding with social media and crowdsourcing data. Comput. Geosci. 2018, 111, 139-147. [CrossRef]

60. Hendler, J. Web 3.0 Emerging. Computer 2009, 42, 111-113. [CrossRef]

61. Garrigos-Simon, F.; Lapiedra Alcami, R.; Barbera Ribera, T. Social networks and Web 3.0: Their impact on the management and marketing of organizations. Manag. Decis. 2012, 50, 1880-1890. [CrossRef]

62. Viero, D. Comment on "Can assimilation of crowdsourced data in hydrological modelling improve flood prediction?" by Mazzoleni et al. (2017). Hydrol. Earth Syst. Sci. 2018, 22, 171. [CrossRef]

63. Dee, D.; Uppala, S.; Simmons, A.; Berrisford, P.; Poli, P.; Kobayashi, S.; Andrae, U.; Balmaseda, M.; Balsamo, G.; Bauer, D.; et al. The ERA-Interim reanalysis: Configuration and performance of the data assimilation system. Q. J. R. Meteorol. Soc. 2011, 137, 553-597. [CrossRef]

(C) 2018 by the authors. Licensee MDPI, Basel, Switzerland. This article is an open access article distributed under the terms and conditions of the Creative Commons Attribution (CC BY) license (http://creativecommons.org/licenses/by/4.0/). 